Article

\title{
Environmental Regulation, Environmental Awareness and Environmental Governance Satisfaction
}

\author{
Meng-Meng Geng ${ }^{1, \dagger}$ and Ling-Yun $\mathrm{He}^{1,2, *, \dagger}$ \\ 1 College of Economics, \& Institute of Resource, Environment and Sustainable Development Research, \\ Jinan University, Guangzhou 510632, China; monameng2018@stu2018.jnu.edu.cn \\ 2 School of Business, Nanjing University of Information Science \& Technology, Nanjing 210044, China \\ * Correspondence: hely_jnu@jnu.edu.cn or lyhe@amss.ac.cn; Tel.: +86-20-181-4571-3770 \\ + These authors contributed equally to this work.
}

Citation: Geng, M.M.; He, L.Y. Environmental Regulation,

Environmental Awareness and Environmental Governance Satisfaction. Sustainability 2021, 13, 3960. https://doi.org/10.3390/ su13073960

Academic Editor: José Manuel Vassallo

Received: 5 January 2021

Accepted: 10 March 2021

Published: 2 April 2021

Publisher's Note: MDPI stays neutral with regard to jurisdictional claims in published maps and institutional affiliations.

Copyright: (c) 2021 by the authors. Licensee MDPI, Basel, Switzerland. This article is an open access article distributed under the terms and conditions of the Creative Commons Attribution (CC BY) license (https:// creativecommons.org/licenses/by/ $4.0 /)$.

\begin{abstract}
It is a problem worth thinking about whether the government's environmental regulation policies can meet the residents' requirements for environmental quality, and benefit the people. The study of the public's subjective evaluation can more intuitively judge whether the government's environmental regulation has realized "ecological benefits for the people". Based on the data of the Chinese General Social Survey (CGSS) in 2013, this paper studied the impact of environmental regulation and environmental awareness on environmental governance satisfaction by an ordered probit model. The study found that environmental regulation has a significant positive impact on environmental governance satisfaction, while environmental awareness has a significant negative impact on environmental governance satisfaction. We also found that when public environmental awareness is taken into account, the positive relationship between environmental regulation and environmental governance satisfaction is affected. The robustness test proved this conclusion.
\end{abstract}

Keywords: environmental regulation; environmental awareness; environmental governance satisfaction

\section{Introduction}

With the rapid development of the economy, the material living standard of Chinese residents has been improved (according to statistics, from 1978 to 2019, the per capita disposable income of Chinese residents increased from 171.2 yuan to 30,732.8 yuan. In 2019, the Engel Coefficient of national residents was 28.2 percent, down 35.7 percentage points from 63.9 percent in 1978 [1]. It shows that the residents' consumption level and consumption structure have been significantly improved with the substantial increase of the income level of the residents in China. It can improve the living standard of residents to some extent.). However, economic development also brings about environmental problems, which further affect the quality of residents' life. According to statistics, in 2017, 239 of the country's 338 cities exceeded the standard of environmental air quality, accounting for $70.7 \%$ [2]. Cardiovascular and cerebrovascular diseases and respiratory diseases, which are closely related to air pollution, accounted for a large proportion of the major causes of death among Chinese residents in 2016, according to the cause-related monitoring data released by the Chinese Center for Disease Control and Prevention. With the deepening understanding of environmental issues, the public awareness of environmental protection has been increasing. Since 1996, pollution-induced environmental mass incidents (environmental mass incidents are mass events caused by environmental problems [3].) have maintained an average annual growth rate of $29 \%$ in China [4], which also reflects the severe situation of environmental pollution in China. Environmental pollution has gradually become one of the common concerns of the country, society, and the public. To cope with severe environmental problems, China has issued a series of environmental regulation policies to strengthen the governance of environmental pollution (for example, in 2007, the central 
government launched the National Specially Monitored Firms (NSMF) program, which placed key industrial polluters under special monitoring at the national level. The essence of the NSMF program is to collect more reliable and accurate information on NSM firms' pollution emissions through direct central supervision [5]. In 2016, China formulated the Environmental Protection Tax Law, which came into force on 1 January 2018. It imposes taxes on all kinds of pollutants. The 40-year-old sewage charge collection system has been replaced by environmental protection tax in China). Public participation is becoming a new drive to implement environmental-related issues for developing countries [6]. When the government's formal regulations are weak, it can improve the environment by exerting social pressure on enterprises to limit their pollution behavior [7]. With the attention to environmental pollution, the policy effect of environmental regulation has become the object of concern by the government and academic circles.

Environmental governance satisfaction is the public's subjective evaluation of the effect of environmental governance, that is, whether they are satisfied with the environmental governance. As an important participant in social activities, the environmental governance measures adopted by the government may be closely related to the life and work of the public. For areas with serious air pollution, the changes in air quality can be intuitively felt by the public. Public satisfaction with environmental governance can be regarded as an important indicator to measure the effect of government environmental regulation. The indicator evaluated the effect of the government environmental regulation from the subjective perspective of the public. From the perspective of national policy, China has clarified the value orientation of socialist ecological civilization, adhering to the principle of "ecological benefits for the people". Therefore, it is a problem worth thinking about whether the government's environmental regulation policies can adhere to the concept that "a good ecological environment is the most beneficial to the people's livelihood", meet the residents' requirements for environmental quality, benefit and serve the people. The study of subjective evaluation can more intuitively judge whether the environmental regulation has realized "ecological benefits for the people". At the same time, when evaluating the effectiveness of government environmental regulation, public participation can supervise the government to formulate and implement environmental regulation policy more comprehensively. Therefore, it is of practical significance to analyze the satisfaction of environmental governance. Most of the existing studies focus on discussing this issue from an objective perspective, such as the impact of environmental regulation on pollution [8-11] and the economy [12-16]. The research from the perspective of subjective evaluation of the effect of environmental governance is relatively insufficient. This paper discusses whether the public is satisfied with the government's current environmental governance measures from a subjective perspective. The study of this problem is conducive to broadening the research perspective on the effect of environmental regulation policies, which has certain academic significance.

Environmental awareness is the public perception of environmental problems. The existing research on environmental awareness mainly focuses on the impact of environmental awareness on environmental pollution [17], behavior [18,19], and innovation [20,21]. However, there are few studies on how environmental awareness affects satisfaction and subjective well-being. As a subjective evaluation, satisfaction is closely related to the public perception of environmental pollution. For example, some scholars have found that environmental awareness can affect investors' emotions towards environmental pollution [22], while emotions can affect people's judgments $[23,24]$. Therefore, we should fully be considered the role of environmental awareness in the study of environmental governance satisfaction. In this paper, when studying the public's satisfaction with environmental governance of environmental regulation, we consider the influence of environmental awareness, enhance the credibility of the conclusions, and make up for the shortcomings of existing research to a certain extent.

Based on the cross-sectional data from the China General Social Survey (CGSS) in 2013, this paper studied the impact of environmental regulation and environmental awareness 
on environmental governance satisfaction by an ordered probit model. It found that the enhancement of environmental regulation can help to improve the public's environmental governance satisfaction, and the enhancement of environmental awareness will weaken the public's environmental satisfaction. When public environmental awareness is taken into account, the positive relationship between environmental regulation and environmental governance satisfaction is affected. Environmental pollution may impact people's perceptual domain and thus affect their well-being [25]. Liao et al. [26] also found that subjective environmental evaluation plays a mediating role between objective environment quality and life satisfaction. Environmental regulation may improve the public's satisfaction with environmental governance by improving the public's subjective perception of environmental quality. Environmental awareness may affect the public's standard of evaluation of environmental governance satisfaction. It may also affect public satisfaction with environmental governance.

The innovation of this paper mainly includes: (1) This paper attempts to evaluate the policy effect of environmental regulation from the public's subjective perspective. It can make up for the shortcomings of existing research in this aspect and broaden the research perspective on the effect of environmental regulation policy. At the same time, it also provides micro-support for urging the government to carry out environmental governance more comprehensively. (2) In this paper, the public's environmental awareness is added to the study of environmental governance satisfaction. It is conducive to improve the accuracy and credibility of the conclusion. At the same time, it also enriches the research on environmental governance satisfaction and environmental awareness.

The rest of this paper is arranged as follows: The second part is a literature review, combing the relevant literature of environmental satisfaction and environmental awareness, the third part is model design and indicator selection and data, the fourth part is the main empirical results of the article, and the fifth part is the conclusion part of the article.

\section{Literature Review}

Satisfaction is a degree that an individual believes that their or her expectations or needs are satisfied [27], which belongs to the field of psychology. As an extended concept, environmental governance satisfaction is the public's subjective evaluation of environmental governance, that is, the extent to which the public believes that environmental governance has met their expectations or needs. By combing the literature, scholars have carried out a lot of research on this subjective indicator that can measure environmental problems. For example, scholars have studied the relationship between environmental pollution and subjective indicators such as life satisfaction and subjective well-being and found that environmental pollution reduces public life satisfaction and subjective well-being [28-35]. Knight and Howley [36] found that there was a significant negative correlation between annual mean nitrogen dioxide and life satisfaction through the analysis of the welfare effect of nitrogen dioxide. However, some studies have also found that the negative impact of environmental pollution on subjective satisfaction may vary depending on the pollutant and region $[37,38]$. Some scholars classified environmental quality from the subjective and objective perspective and further analyzed the relationship between subjective and objective environmental quality, life satisfaction, and subjective well-being. Silva et al. [39] found that the actual and perceived environmental quality had a significant impact on life satisfaction. Previous studies using data on the individual or national level have reached similar conclusions [40-42]. Liao et al. [26] found that objective air quality had no direct impact on life satisfaction, but it could have an indirect effect through the perception of air quality. Li et al. [43] also believe that perceived environmental risk is one of the important ways for air pollution to subjective happiness reduction. The study of Chen et al. [34] also provides evidence that air pollution corrupts public satisfaction with the perceived environment. Wang and Cheng [44] believe that environmental pollution has a direct impact on subjective well-being, but the correlation between the perception of the seriousness of environmental problems and subjective well-being is very limited. 
In general, existing researches have a mixed understanding of the relationship between environmental pollution, life satisfaction, and subjective well-being.

Scholars also began to try to study the relationship between environmental pollution control and satisfaction. Song et al. [45] studied the impact of various air pollution control measures on the well-being of urban residents with micro-data. Guo et al. [6] combined with the micro-data of CGSS and the macro-data of 28 provinces in China, studied the impact of economical environmental regulation, legal environmental regulation, and supervised environmental regulation on public well-being. He found that economical environmental regulation can significantly enhance happiness; supervised environmental regulation may reduce happiness; legal environmental regulation has a neutral relationship with happiness. However, compared with the extensive attention caused by the relationship between environmental pollution and satisfaction, existing studies have ignored the impact of environmental governance on satisfaction, lacking the research on public satisfaction with environmental governance [6]. This paper takes the public's satisfaction with environmental governance as the main research object to make up for the deficiencies in existing studies.

Environmental awareness is a concept involving psychology, sociology, environmental science, and other disciplines. At present, people have not formed a generally accepted definition of environmental awareness. For example, some scholars think that environmental awareness is a part of environmental literacy, which can be defined as a combination of motivation, knowledge, and skills [46]. Some scholars believe that environmental awareness can be broadly defined as an attitude towards the environmental consequences of human behavior [47]. Environmental awareness also can be defined as an individual's ability to understand the relationship between human activities, the state of environmental quality, and their or her willingness to participate in environmental activities $[48,49]$. This paper defines environmental awareness as the public's perception of environmental problems, which is embodied in whether the public has realized the environmental pollution problem. Existing research on environmental awareness mainly focuses on the impact of environmental attitude and awareness on environmental pollution [50,51], and environmental behavior [52-54], as well as the impact of other factors on environmental attitude [52,55,56]. As the public's cognition degree of environmental problems, environmental awareness will also affect their life satisfaction and subjective happiness [57]. Ferrer-i-carbonell and Gowdy [58] investigated the relationship between subjective well-being and environmental attitudes using survey data from a British family group and found that concerns about ozone status were negatively correlated with subjective well-being, while concerns about species extinction were positively correlated with subjective well-being. This shows that environmental awareness will affect their judgment and evaluation of environmental satisfaction and happiness. As a subjective criterion, whether the public is satisfied with the environmental governance is closely related to their awareness and expectation of the environment. Therefore, it is necessary to incorporate public environmental awareness into the research when analyzing environmental governance satisfaction. However, the existing literature on environmental awareness and environmental governance satisfaction is insufficient.

In summary, this paper will combine the micro-data of CGSS (2013) and the macrodata of China's cities to explore the effect of environmental regulation and environmental awareness on environmental governance satisfaction. This study is helpful to broaden the research perspective of the effect of an environmental regulation policy, enrich the study of environmental governance satisfaction, and have certain research significance.

\section{Method, Variables and Data}

\subsection{Model Setting and Index Selection}

This paper aims to explore the impact of environmental regulation and environmental awareness on environmental governance satisfaction. The environmental governance satisfaction adopts the data of the Chinese General Social Survey (CGSS) in 2013. The two 
indicators selected in this article are "what do you think the central government has done in environmental protection work over the past five years?" and "what do you think the local government has done in environmental protection work over the past five years?". The indicators range from 1 to 5 . Among them, 1 refers to the one-sided emphasis on economic development and neglect of environmental protection, 2 refers to the insufficient attention to environmental protection and investment, 3 refers to efforts but poor results, 4 refers to great efforts and achieved certain results, 5 refers to great achievements. Since the indicator of environmental governance satisfaction is an ordered discrete variable ranging from 1 to 5, this paper will choose an ordered probit model to estimate public satisfaction. The interpreted variables are environmental governance satisfaction. The core explanatory variables are environmental awareness and environmental regulation. A series of other factors that may affect environmental governance satisfaction are introduced as control variables. The model constructed is as follows:

$$
\begin{aligned}
& \text { Satisfaction }_{i j}=\mathrm{F}\left(\text { RRegulation }_{j}+\gamma p_{i j}+\varphi q_{j}+\varepsilon_{i j}\right) \\
& \text { Satisfaction }_{i j}=\mathrm{F}\left(\beta \text { Awarenesse }_{i j}+\gamma p_{i j}+\varphi q_{j}+\varepsilon_{i j}\right)
\end{aligned}
$$

$\mathrm{F}(\cdot)$ is a nonlinear function, and its specific form is as follows:

$$
\mathrm{F}\left(\text { Satisfaction }_{i j}^{*}\right)=\left\{\begin{array}{l}
1 . \text { Satisfaction }_{i j}^{*} \leq \gamma_{0} \\
2 \cdot \gamma_{0}<\text { Satisfaction }_{i j}^{*} \leq \gamma_{1} \\
3 \cdot \gamma_{1}<\text { Satisfaction }_{i j}^{*} \leq \gamma_{2} \\
\cdots . . . \\
J \cdot \gamma_{J-1}<\text { Satisfaction }_{i j}^{*}
\end{array}\right.
$$

Satisfaction $_{i j}^{*}$ is an unobservable continuous variable behind Satisfaction ${ }_{i j}$, which is called a latent variable, and satisfy:

$$
\begin{aligned}
& \text { Satisfaction }_{i j}=\alpha \text { Regulation }_{j}+\gamma p_{i j}+\varphi q_{j}+\varepsilon_{i j} \\
& \text { Satisfaction }_{i j}=\beta \text { Awareness }_{i j}+\gamma p_{i j}+\varphi q_{j}+\varepsilon_{i j}
\end{aligned}
$$

Among them, $i$ stands for individual, $j$ stands for city, Satisfaction $n_{i j}$ is the satisfaction degree of public environmental governance, Awareness $i j$ is the environmental awareness of $i$ in city $j$, Regulation ${ }_{j}$ is the environmental regulation of city $j, p_{i j}$ is the individual characteristics of $i$ in city $j, q_{j}$ is the characteristics that may affect public satisfaction, and $\varepsilon_{i j}$ is random disturbance term. The interpreted variable is the environmental governance satisfaction in China. This paper adopts the data of b23 "what do you think the central government has done in environmental protection work over the past five years?" and b24 "what do you think the local government has done in environmental protection work over the past five years?" in CGSS (2013). They take values from 1 to 5.

The core explanatory variables are environmental awareness and environmental regulation. The environmental awareness indicator is "are you aware of the following types of environmental issues?", provided by the Chinese General Social Survey (CGSS) in 2013. There are twelve kinds of environmental problems, including air pollution, water pollution, noise pollution, industrial waste pollution, domestic waste pollution, green space shortage, forest vegetation damage, farmland quality degradation, freshwater resources shortage, food pollution, desertification, and wildlife reduction. Combined with the selection of environmental regulation indicators, this paper mainly chooses the cognition of air pollution and water pollution. b21a01 is "are you aware of air pollution", and b21a02 is "are you aware of water pollution". If the answer is yes, the value is 1 , otherwise, the value is 0. According to Cole and Elliott [59], this paper uses the ratio of pollutant emission to industrial added value to measure environmental regulation (scholars at home and abroad mainly measure the intensity of environmental regulation policies by using the proportion of investment in environmental governance [60], per capita income level [61], sewage tax 
income [62], pollutant emissions [59,63], etc.). This is mainly because when assessing the quality of the environment, we pay more attention to the emissions of various pollutants, especially industrial pollutants. The stronger the environmental regulation, the smaller the emissions of pollutants and the smaller the emissions per unit of industrial value-added. In this paper, the entropy weight method is used to synthesize the ratio of industrial wastewater discharge to industrial added value, industrial sulfur dioxide emission to industrial added value, and industrial smoke (powder) dust emission to industrial added value. The smaller the value of the comprehensive index indicates that the stronger the environmental regulation.

Other control variables are the main variables that may affect public satisfaction with environmental governance. Based on the relevant research, this paper introduces a series of control variables that may affect public satisfaction with environmental governance from the aspects of individual public and urban characteristics. The individual characteristics mainly include gender, age, nationality, personal annual income, education level, political outlook, physical health, mood, marital status, social and economic status. Urban characteristics mainly include GDP per capita (yuan), the proportion of the secondary industry (\%), the proportion of the tertiary industry $(\%)$, urban registered unemployment rate $(\%)$, the average wage of employees (yuan), number of broadband access users (10,000 households), population density (person/square kilometer), annual average temperature $\left({ }^{\circ} \mathrm{C}\right)$, annual relative humidity (\%), sunshine hours (hours), and annual precipitation (mm).

\subsection{Data Introduction and Descriptive Analysis}

In this paper, the data of environmental governance satisfaction, environmental awareness, and other variables of individual characteristics are from the Chinese General Social Survey (CGSS). The survey was conducted by the China Survey and data center of the Renmin University of China. It is the earliest national, comprehensive, and continuous academic survey project in China. It systematically and comprehensively collects data from society, community, family, and individuals. The project started in 2003, once a year, to conduct a continuous cross-sectional survey of more than 10,000 households in each province and autonomous region of China. To date, a total of ten surveys have been conducted (in 2003, 2005, 2006, 2008, 2010, 2011, 2012, 2013, 2015, and 2017). The cross-sectional survey data of 2013 is selected in this paper. The data of urban characteristic variables in other control variables are from the China Statistical Yearbook, China Environmental Statistical Yearbook, and China environment database in EPS. The CGSS (2013) investigates residents' perceptions of government environmental regulation over the past five years. The environmental regulation variable will be constructed from the industrial wastewater emissions, industrial sulfur dioxide emissions, industrial smoke (powder) emissions, and industrial added value during the period 2009 2013. In this paper, the average ratio of pollutant emissions to industrial value-added from 2009 to 2013 is calculated, and a comprehensive value is obtained by using the entropy weight method.

According to the city code (S42), the data of individual characteristics and urban characteristics were merged. Samples with "unclear", "not applicable" and "refused to answer" were deleted. After matching, this paper obtained 9109 sample data from 83 cities. Tables 1 and 2 shows the specific measurement methods and descriptive statistics of each variable. Figure 1 shows the specific distribution of the explained variables. $38.35 \%$ and $33.71 \%$ of the residents think that the central government and the local government have made great efforts and achieved some success in environmental governance, which accounts for the largest proportion in the distribution of environmental governance satisfaction. However, the proportion of the public thinks that the central government and local government have made great achievements in environmental governance is the least, accounting for $9.45 \%$ and $8.31 \%$ respectively. Overall, the sample distribution is relatively comprehensive. 
Table 1. Measurement methods and descriptive statistics of main variables.

\begin{tabular}{|c|c|c|c|c|c|c|c|}
\hline & Variable & Measurement Method & Obs & Mean & Std. Dev. & Min & Max \\
\hline \multirow[t]{2}{*}{ Interpreted variables } & $\begin{array}{l}\text { Environmental Governance } \\
\text { Satisfaction }\end{array}$ & $\begin{array}{l}\text { According to b23, "what do you think the central government has } \\
\text { done in environmental protection work over the past five years?" } \\
\text { The answers are "one sidedly focusing on economic development, } \\
\text { ignoring environmental protection work", "insufficient attention, in- } \\
\text { sufficient investment in environmental protection", "efforts made, } \\
\text { but the effect is not good", "great efforts have been made to achieve } \\
\text { some success" and "great achievements have been made", with val- } \\
\text { ues of 1-5. Delete the samples with the answers of "unclear", "not } \\
\text { applicable" and "refuse to answer". }\end{array}$ & 9109 & 3.2120 & 1.1281 & 1 & 5 \\
\hline & & $\begin{array}{l}\text { According to b24, "what do you think the local government has done } \\
\text { in environmental protection work over the past five years?" The an- } \\
\text { swers are "one sidedly focusing on economic development, ignoring } \\
\text { environmental protection work", "insufficient attention, insufficient } \\
\text { investment in environmental protection", "efforts made, but the effect } \\
\text { is not good", "great efforts have been made to achieve some success" } \\
\text { and "great achievements have been made", with values of 1-5. Delete } \\
\text { the samples with the answers of "unclear", "not applicable" and } \\
\text { "refuse to answer". }\end{array}$ & 9109 & 3.0314 & 1.1775 & 1 & 5 \\
\hline \multirow[t]{3}{*}{$\begin{array}{l}\text { Core explanatory } \\
\text { variables }\end{array}$} & Environmental Regulation & $\begin{array}{l}\text { According to Cole and Elliott [59], the ratio of pollutant emission to } \\
\text { industrial added value from } 2009 \text { to } 2013 \text { is used to measure. The ratio } \\
\text { of industrial wastewater discharge to industrial added value, the ra- } \\
\text { tio of industrial sulfur dioxide emission to industrial added value, } \\
\text { and the ratio of industrial smoke (powder) dust emission to industrial } \\
\text { added value were synthesized by the entropy weight method. }\end{array}$ & 9109 & 0.0122 & 0.0009 & 0.0089 & 0.0130 \\
\hline & Are you aware of air pollution? & According to $\mathrm{b} 21 \mathrm{a} 01, \mathrm{yes}=1, \mathrm{no}=0$ & 9107 & 0.9354 & 0.2458 & 0 & 1 \\
\hline & $\begin{array}{l}\text { Are you aware of water pollu- } \\
\text { tion? }\end{array}$ & According to b21a02, yes $=1$, no $=0$ & 9107 & 0.9291 & 0.2567 & 0 & 1 \\
\hline
\end{tabular}


Table 1. Cont

\begin{tabular}{|c|c|c|c|c|c|c|c|}
\hline & Variable & Measurement Method & Obs & Mean & Std. Dev. & Min & Max \\
\hline \multirow{7}{*}{ Control variables } & gender & According to a2, male $=1$, female $=0$ & 9109 & 0.5223 & 0.4995 & 0 & 1 \\
\hline & age & $\begin{array}{l}\text { According to a3, the year of the interview (2013) minus the year } \\
\text { of birth }\end{array}$ & 9109 & 47.6180 & 16.0740 & 17 & 96 \\
\hline & nation & According to $44, \operatorname{Han}=1$, others $=0$ & 9100 & 0.9140 & 0.2804 & 0 & 1 \\
\hline & degree of education & $\begin{array}{l}\text { According to a7a, it is assigned according to the number of years of } \\
\text { education in each stage. No education = 0; Primary school and private } \\
\text { school =6; junior middle school =9; Technical secondary school, } \\
\text { higher vocational school, senior high school, and technical school } \\
=12 \text {; College (Adult Education), College (higher), and other =14; } \\
\text { Undergraduate (Advanced) =16; Graduate or above }=19\end{array}$ & 9107 & 9.2060 & 4.2942 & 0 & 19 \\
\hline & Personal annual income last year & According to a8a, take logarithm & 8200 & 8.7363 & 3.1245 & 0 & 13.8160 \\
\hline & Political outlook & According to a10, communists $=1$, others $=0$ & 9070 & 0.1179 & 0.3225 & 0 & 1 \\
\hline & health & $\begin{array}{l}\text { According to a15, very unhealthy }=1 \text {, less healthy }=2 \text {, general }=3 \text {, } \\
\text { relatively healthy }=4 \text {, very healthy }=5\end{array}$ & 9108 & 3.7744 & 1.0487 & 1 & 5 \\
\hline
\end{tabular}

Table 2. Measurement methods and descriptive statistics of main variables.

\begin{tabular}{|c|c|c|c|c|c|c|c|}
\hline & Variable & Measurement Method & Obs & Mean & Std. Dev. & Min & Max \\
\hline \multirow{15}{*}{ Control variables } & $\begin{array}{l}\text { What level do you think you are cur- } \\
\text { rently in? }\end{array}$ & According to a43a, 10 is the top layer and 1 is the lowest layer & 9087 & 4.4155 & 1.6624 & 1 & 10 \\
\hline & Marital status & According to a69, married $=1$, others $=0$ & 9093 & 0.8604 & 0.3465 & 0 & 1 \\
\hline & $\begin{array}{l}\text { Socioeconomic status compared with } \\
\text { peers }\end{array}$ & According to $b 1$, higher or almost $=1$, decrease $=0$ & 8760 & 1.7144 & 0.5539 & 1 & 3 \\
\hline & Average wage of employees & Yuan; Logarithm & 9109 & 10.6080 & 0.3116 & 10.0240 & 11.2490 \\
\hline & GDP & Ten thousand yuan; Logarithm & 9109 & 16.9370 & 1.2186 & 14.6690 & 19.0430 \\
\hline & Per capita GDP & Yuan; Logarithm & 9109 & 10.5570 & 0.6676 & 9.0696 & 11.6640 \\
\hline & Proportion of secondary industry & $\%$ & 9109 & 47.2420 & 10.4260 & 16.9760 & 72.3260 \\
\hline & Proportion of tertiary industry & $\%$ & 9109 & 41.9120 & 13.3610 & 18.5040 & 76.0040 \\
\hline & Urban unemployment rate & $\%$ & 9109 & 3.2064 & 0.8039 & 1.3250 & 4.3750 \\
\hline & Population density & Person/square kilometer; Logarithm & 9109 & 5.9932 & 0.8521 & 3.1278 & 7.7129 \\
\hline & $\begin{array}{l}\text { Number of Internet broadband access } \\
\text { households }\end{array}$ & Ten thousand households; Logarithm & 9109 & 4.4291 & 1.3261 & 1.8669 & 6.8700 \\
\hline & Average temperature & ${ }^{\circ} \mathrm{C}$; Logarithm & 9109 & 2.5696 & 0.4487 & 1.1314 & 3.1311 \\
\hline & Average relative humidity & $\%$ & 9109 & 67.2800 & 10.1540 & 47 & \\
\hline & Sunshine hours & Hour; Logarithm & 9109 & 7.4687 & 0.3513 & 6.5244 & 8.0063 \\
\hline & Precipitation & Millimeter; Logarithm & 9109 & 6.843 & 0.5015 & 5.4996 & 7.7046 \\
\hline
\end{tabular}




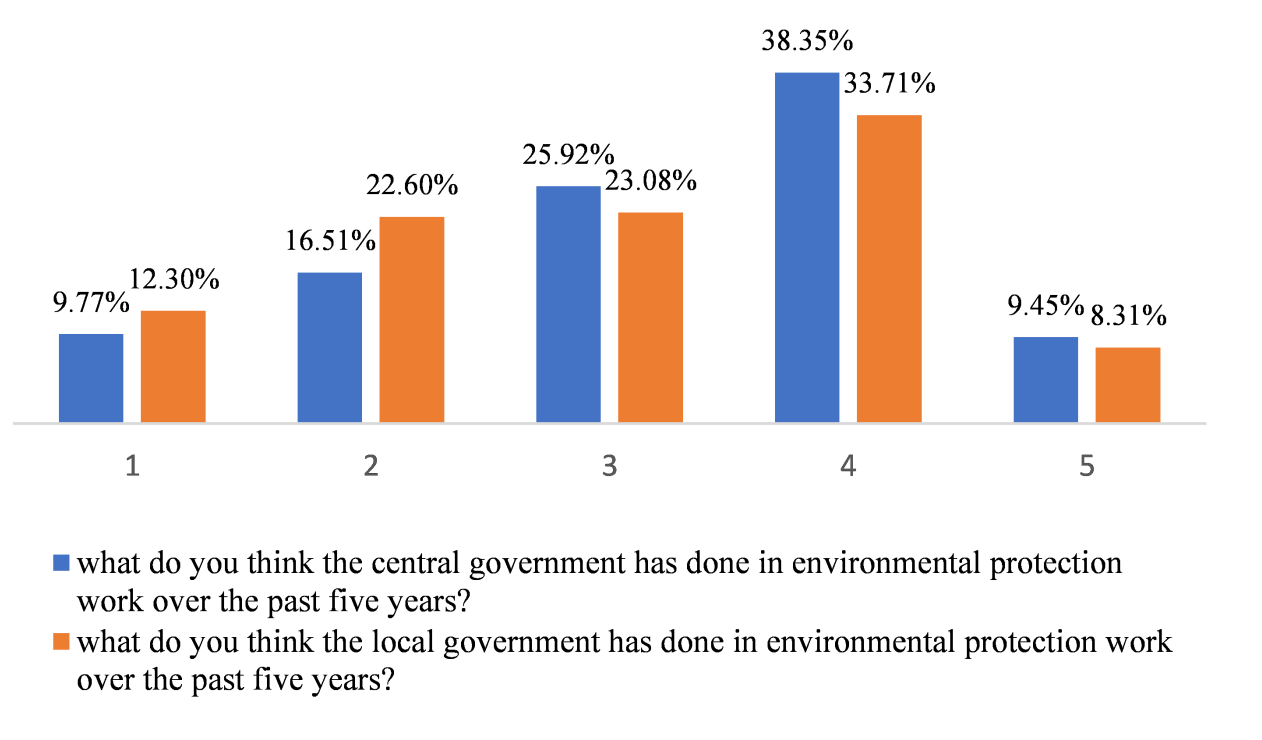

Figure 1. Distribution of environmental governance satisfaction

\section{Results and Discussion}

\subsection{Basic Empirical Results}

In this section, we first analyze the impact of environmental regulation and environmental awareness on environmental governance satisfaction. Then we discuss the interaction between environmental regulation and environmental awareness, that is, whether the environmental awareness will affect the environmental governance satisfaction brought about by environmental regulation.

\subsubsection{The Impact of Environmental Regulation on Environmental Governance Satisfaction}

Combined with Equation (1), this part first analyzes the impact of environmental regulation on environmental governance satisfaction. The results are shown in Table 3 . Among them, b23 and b24 are indicators of environmental governance satisfaction. These two indicators represent "what do you think the central government has done in environmental protection work over the past five years?" and "what do you think the local government has done in environmental protection work over the past five years?". The environmental regulation indicator uses the ratio of emissions of various pollutants to industrial value-added, and the smaller the value, the stronger the environmental regulation. That is, the value of regulation has a negative relationship with environmental regulation. It can be seen from Table 3 that whether or not the control variables of individual characteristics and urban characteristics are added, the value of the environmental regulation indicator is negatively correlated with the indicator of environmental satisfaction. That is, the relationship between environmental regulation and environmental governance satisfaction is positive, and significant at the level of $1 \%$. It indicates that the smaller the value of the environmental regulation indicator and the stronger the environmental regulation, the greater the satisfaction of the public with environmental governance.

Environmental governance satisfaction may also affect the formulation and implementation of government environmental regulation policies. That is, there may be a two-way causal relationship between environmental governance satisfaction and environmental regulation. To solve the problem of endogeneity caused by two-way causation, the most commonly used method is to use instrumental variables. It is not easy to find completely exogenous tool variables. Some articles used the mean value as a tool variable to solve the potential problem of endogeneity [64]. This paper discusses the public's satisfaction with the government's environmental governance in the last five years. Environmental regulation indicators and urban characteristics indicators adopt the average value from 
2009 to 2013. To some extent, the use of the mean value of environmental regulation can alleviate the possible two-way causal relationship between environmental regulation and environmental governance satisfaction.

Table 3. The impact of environmental regulation on environmental governance satisfaction.

\begin{tabular}{lllllll}
\hline & $\mathbf{b 2 3}$ & $\mathbf{b 2 3}$ & $\mathbf{b 2 3}$ & $\mathbf{b 2 4}$ & $\mathbf{b 2 4}$ & b24 \\
\hline regulation & $-149.691^{* * *}$ & $-118.881^{* * * *}$ & $-67.213^{* * *}$ & $-63.560^{* * *}$ & $-58.701^{* * *}$ & $-93.100^{* * * *}$ \\
& {$[-11.95]$} & {$[-8.69]$} & {$[-3.85]$} & {$[-5.12]$} & {$[-4.33]$} & {$[-5.37]$} \\
Individual control variable & NO & YES & YES & NO & YES & YES \\
Urban control variable & NO & NO & YES & NO & NO & YES \\
\hline $\mathrm{N}$ & 9109 & 7844 & 7844 & 9109 & 7844 & 7844 \\
\hline
\end{tabular}

4.1.2. The Impact of Environmental Awareness on Environmental Governance Satisfaction

Combined with Equation (2), this part focuses on the impact of public environmental awareness on environmental governance satisfaction. The results are shown in Table 4 . The environmental awareness in this paper refers to the public's awareness of environmental pollution, that is, whether they are aware of or know about environmental pollution. In this paper, we choose the cognition of "are you aware of air pollution" (b21a01) and "are you aware of water pollution" (b21a02) which are closely related to public life. As shown in Table 4, whether it is the perception of air pollution or water pollution, and whether or not to add control variables of individual characteristics and urban characteristics, environmental awareness is negatively related to environmental governance satisfaction. It is significant at the level of $1 \%$ or $5 \%$. It indicates that if the public awareness of environmental pollution is deepened, the satisfaction with environmental governance will decline.

Table 4. The impact of environmental awareness on environmental governance satisfaction.

\begin{tabular}{|c|c|c|c|c|c|c|}
\hline & b23 & b23 & b23 & b24 & b24 & b24 \\
\hline \multicolumn{7}{|c|}{ Panel A: Are you aware of air pollution? } \\
\hline $\mathrm{b} 21 \mathrm{a} 01$ & $\begin{array}{c}-0.290 * * * \\
{[-6.43]}\end{array}$ & $\begin{array}{c}-0.163 \text { ** } \\
{[-3.14]}\end{array}$ & $\begin{array}{c}-0.164^{* *} \\
{[-3.13]}\end{array}$ & $\begin{array}{c}-0.167^{* * *} \\
{[-3.73]}\end{array}$ & $\begin{array}{c}-0.140 * * \\
{[-2.73]}\end{array}$ & $\begin{array}{c}-0.160 * * \\
{[-3.09]}\end{array}$ \\
\hline Individual control variable & NO & YES & YES & NO & YES & YES \\
\hline Urban control variable & NO & $\mathrm{NO}$ & YES & NO & NO & YES \\
\hline \multicolumn{7}{|c|}{ Panel B: Are you aware of water pollution? } \\
\hline b21a02 & $\begin{array}{c}-0.286^{* * *} \\
{[-6.62]}\end{array}$ & $\begin{array}{c}-0.206^{* * *} \\
{[-4.19]}\end{array}$ & $\begin{array}{c}-0.201^{* * *} \\
{[-4.07]}\end{array}$ & $\begin{array}{c}-0.211^{* * *} \\
{[-4.92]}\end{array}$ & $\begin{array}{c}-0.187^{* * *} \\
{[-3.84]}\end{array}$ & $\begin{array}{c}-0.187^{* * * *} \\
{[-3.82]}\end{array}$ \\
\hline Individual control variable & $\mathrm{NO}$ & YES & YES & $\mathrm{NO}$ & YES & YES \\
\hline Urban control variable & $\mathrm{NO}$ & $\mathrm{NO}$ & YES & $\mathrm{NO}$ & $\mathrm{NO}$ & YES \\
\hline $\mathrm{N}$ & 9107 & 7842 & 7842 & 9107 & 7842 & 7842 \\
\hline
\end{tabular}

Note: ${ }^{* * *} 1 \%, * * 5 \% ; Z$ value in parentheses.

\subsubsection{The Weakening Effect of Environmental Awareness}

The first two parts, respectively, analyze the impact of environmental regulation and environmental awareness on environmental governance satisfaction. It is found that the enhancement of environmental regulation will enhance environmental governance satisfaction, while environmental awareness will weaken environmental governance satisfaction. It is worth studying that whether the impact of these two explanatory variables on environmental governance satisfaction is independent or interactive. This part discusses this issue by estimating Equations (6) and (7) (the definitions of variables are the same as before). 
It focuses on the coefficient $\mu$ of the interaction between environmental regulation and environmental awareness. The specific results are shown in Tables 5 and 6.

$$
\text { Satisfaction }_{i j}=\mathrm{F}\left(\alpha \text { Regulation }_{j}+\beta \text { Awareness }_{i j}+\gamma p_{i j}+\varphi q_{j}+\varepsilon_{i j}\right)
$$

$$
\text { Satisfaction }_{i j}=\mathrm{F}\left({\alpha \text { Regulation }_{j}}+\text { BAwareness }_{i j}+\mu \text { Regulation }_{j} * \text { Awareness }_{i j}+\gamma p_{i j}+\varphi q_{j}+\varepsilon_{i j}\right)
$$

\begin{tabular}{|c|c|c|c|c|c|c|}
\hline & b23 & b23 & b23 & b24 & b24 & b24 \\
\hline \multicolumn{7}{|l|}{ Panel A: No Interactive item } \\
\hline \multirow[t]{2}{*}{ regulation } & $-149.889^{* * *}$ & $-119.437^{* * *}$ & $-68.540^{* * *}$ & $-63.468^{* * *}$ & $-59.145^{* * *}$ & $-94.443^{* * *}$ \\
\hline & {$[-11.96]$} & {$[-8.73]$} & {$[-3.92]$} & {$[-5.11]$} & {$[-4.37]$} & {$[-5.44]$} \\
\hline \multirow[t]{2}{*}{ b21a01 } & $-0.292^{* * *}$ & $-0.168^{* *}$ & $-0.168^{* *}$ & $-0.167^{* * *}$ & $-0.142^{* *}$ & $-0.166^{* *}$ \\
\hline & {$[-6.46]$} & {$[-3.24]$} & {$[-3.22]$} & {$[-3.73]$} & {$[-2.77]$} & {$[-3.20]$} \\
\hline Individual control variable & $\mathrm{NO}$ & YES & YES & $\mathrm{NO}$ & YES & YES \\
\hline Urban control variable & NO & $\mathrm{NO}$ & YES & $\mathrm{NO}$ & $\mathrm{NO}$ & YES \\
\hline \multicolumn{7}{|l|}{ Panel B: Interactive item } \\
\hline \multirow[t]{2}{*}{ regulation } & $-204.391^{* * *}$ & -109.288 & -90.833 & $-127.050 *$ & -64.179 & -105.713 \\
\hline & {$[-3.64]$} & {$[-1.77]$} & {$[-1.45]$} & {$[-2.32]$} & {$[-1.07]$} & {$[-1.74]$} \\
\hline \multirow[t]{2}{*}{ b21a01 } & -0.992 & -0.039 & -0.455 & -0.985 & -0.207 & -0.311 \\
\hline & {$[-1.41]$} & {$[-0.05]$} & {$[-0.59]$} & {$[-1.43]$} & {$[-0.28]$} & {$[-0.41]$} \\
\hline \multirow[t]{2}{*}{ regulation * b21a01 } & 57.335 & -10.64 & 23.613 & 67.02 & 5.287 & 11.965 \\
\hline & [0.99] & {$[-0.17]$} & {$[0.37]$} & [1.19] & [0.09] & {$[0.19]$} \\
\hline Individual control variable & $\mathrm{NO}$ & YES & YES & $\mathrm{NO}$ & YES & YES \\
\hline Urban control variable & NO & NO & YES & NO & $\mathrm{NO}$ & YES \\
\hline $\mathrm{N}$ & 9107 & 7842 & 7842 & 9107 & 7842 & 7842 \\
\hline
\end{tabular}

Table 5. The weakening effect of environmental awareness.

Note: $* * * 1 \%, * * 5 \%, * 10 \% ; Z$ value in parentheses.

\begin{tabular}{|c|c|c|c|c|c|c|}
\hline & b23 & b23 & b23 & b24 & b24 & b24 \\
\hline \multicolumn{7}{|l|}{ Panel A: No Interactive item } \\
\hline \multirow[t]{2}{*}{ regulation } & $-151.467^{* * *}$ & $-120.659^{* * *}$ & $-69.310^{* * *}$ & $-64.566^{* * *}$ & $-60.191 * * *$ & $-95.134^{* * *}$ \\
\hline & {$[-12.08]$} & {$[-8.82]$} & {$[-3.97]$} & {$[-5.20]$} & {$[-4.44]$} & {$[-5.48]$} \\
\hline \multirow[t]{2}{*}{ b21a02 } & $-0.297^{* * *}$ & $-0.218 * * *$ & $-0.207^{* * *}$ & $-0.215^{* * *}$ & $-0.193^{* * *}$ & $-0.195^{* * *}$ \\
\hline & {$[-6.86]$} & {$[-4.44]$} & {$[-4.18]$} & {$[-5.01]$} & {$[-3.95]$} & {$[-3.96]$} \\
\hline \multirow{2}{*}{$\begin{array}{l}\text { Individual control variable } \\
\text { Urban control variable }\end{array}$} & $\mathrm{NO}$ & YES & YES & NO & YES & YES \\
\hline & $\mathrm{NO}$ & $\mathrm{NO}$ & YES & NO & $\mathrm{NO}$ & YES \\
\hline \multicolumn{7}{|l|}{ Panel B: Interactive item } \\
\hline \multirow[t]{2}{*}{ regulation } & $-266.982^{* * *}$ & $-166.936^{* *}$ & $-167.570^{* *}$ & $-138.114^{*}$ & -63.624 & $-124.334 *$ \\
\hline & {$[-4.80]$} & {$[-2.65]$} & {$[-2.61]$} & {$[-2.56]$} & {$[-1.04]$} & {$[-2.01]$} \\
\hline \multirow[t]{2}{*}{ b21a02 } & $-1.789 *$ & -0.811 & -1.473 & -1.167 & -0.237 & -0.572 \\
\hline & {$[-2.55]$} & {$[-1.03]$} & {$[-1.85]$} & {$[-1.72]$} & {$[-0.31]$} & {$[-0.74]$} \\
\hline \multirow[t]{2}{*}{ regulation * b21a02 } & $121.677^{*}$ & 48.399 & 103.475 & 77.655 & 3.598 & 30.836 \\
\hline & [2.13] & {$[0.75]$} & [1.59] & {$[1.40]$} & {$[0.06]$} & {$[0.49]$} \\
\hline Individual control variable & NO & YES & YES & $\mathrm{NO}$ & YES & YES \\
\hline Urban control variable & $\mathrm{NO}$ & $\mathrm{NO}$ & YES & $\mathrm{NO}$ & $\mathrm{NO}$ & YES \\
\hline $\mathrm{N}$ & 9107 & 7842 & 7842 & 9107 & 7842 & 7842 \\
\hline
\end{tabular}

Table 6. The weakening effect of environmental awareness.

Panel A in Table 5 and Panel A in Table 6 show that when considering both environmental regulation and environmental awareness, the direction of the effect of environmental regulation and environmental awareness on environmental governance satisfaction does not change without adding the interaction between them. No matter whether the indi- 
vidual characteristics variables and urban characteristics variables are included or not, the relationship between environmental regulation and environmental governance satisfaction is positive, and environmental awareness is negatively related to environmental governance satisfaction, which is significant at the level of $1 \%$ or $5 \%$. When the interactive item between environmental regulation and environmental awareness is added, the coefficient of environmental regulation is negative. However, the coefficients of interaction between environmental regulation and environmental awareness are positive. When public environmental awareness is taken into account, the positive relationship between environmental regulation and environmental governance satisfaction is affected. The possible explanation is that when the public has a certain degree of environmental awareness, their requirements for environmental quality will be higher. It is more difficult to improve the public satisfaction with environmental governance.

\subsection{Robustness Test}

In the previous sections, we analyze the impact of environmental regulation and environmental awareness on environmental governance satisfaction and found that the relationship between environmental regulation and environmental governance satisfaction is positive, while environmental awareness is negatively related to environmental governance satisfaction. That is, environmental regulation can improve environmental governance satisfaction, while environmental awareness will weaken environmental governance satisfaction. We also found that when public environmental awareness is taken into account, the positive relationship between environmental regulation and environmental governance satisfaction is affected. To verify these conclusions, we will use different environmental regulation indicators and environmental awareness indicators to test the robustness. Firstly, environmental regulation indicators remain unchanged, and different environmental awareness indicators are selected. This paper selects the understanding of environmental protection knowledge in CGSS (2013). It mainly includes b2507 "grade III air quality means better than grade I air quality in the air quality report" and b2509 "class $\mathrm{V}$ water quality means better than class I water quality in the water pollution report". If the answer is correct, the value is 1 ; otherwise, the value is 0 . Panel A in Table 7 shows that the coefficients of environmental regulation are significantly negative. That is, the relationship between environmental regulation and environmental governance satisfaction is significantly positive. The coefficients of interaction between environmental regulation and environmental awareness are still negative, but not significant. Although the coefficient of interaction between environmental regulation and b21a07 is significantly negative. However, the coefficient is significantly lower than that of environmental regulation. It confirms that environmental awareness will affect the positive relationship between environmental regulation and environmental governance satisfaction. The second method is to simultaneously modify the environmental regulation indicators and the environmental awareness indicators. The environmental regulation will be represented by a new indicator, which is a positive indicator. It was synthesized by sulfur dioxide removal rate, soot removal rate, industrial solid waste comprehensive utilization rate, sewage treatment rate, and harmless treatment rate of household waste. In CGSS (2013), b21a04 "are you aware of industrial waste pollution" and b21a10 "are you aware of food pollution" were selected as environmental awareness indicators. If the answer is yes, the value is 1 ; otherwise, the value is 0 . Panel B in Table 7 shows that the coefficients of environmental regulation are significantly positive. It indicates that the relationship between environmental regulation and environmental governance satisfaction is significantly positive. While the coefficients of interaction between environmental regulation and environmental awareness are negative, with a certain significance. It shows that when environmental awareness is taken into account, the positive relationship between environmental regulation and environmental governance satisfaction is affected.

In this part, the main conclusions are tested for robustness by selecting different environmental regulation indicators and environmental awareness indicators. Furthermore, 
the main conclusions can be confirmed by the robustness test. That is, the relationship between environmental regulation and environmental governance satisfaction is positive. When environmental awareness is taken into account, the positive relationship between environmental regulation and environmental governance satisfaction is affected.

Table 7. Robustness test.

\begin{tabular}{|c|c|c|c|c|}
\hline & b23 & b24 & b23 & b24 \\
\hline \multicolumn{5}{|c|}{ Panel A: environmental regulation indicators remain unchanged, and environmental awareness indicators changec } \\
\hline regulation & $-59.705^{* *}$ & $\begin{array}{c}-78.983^{* * *} \\
{[-414]}\end{array}$ & & \\
\hline \multirow{2}{*}{ b2507 } & {$\left[\begin{array}{l}-3.11] \\
0.402\end{array}\right.$} & {$\left[\begin{array}{c}-4.14] \\
0.679\end{array}\right.$} & & \\
\hline & [1.10] & [1.87] & & \\
\hline \multirow[t]{2}{*}{ regulation * b2507 } & -42.884 & $-65.695 *$ & & \\
\hline & {$[-1.44]$} & {$[-2.22]$} & & \\
\hline \multirow[t]{2}{*}{ regulation } & & & $-58.914^{* *}$ & $-86.454 * * *$ \\
\hline & & & {$[-3.16]$} & [-4.67] \\
\hline \multirow[t]{2}{*}{ b2509 } & & & 0.542 & 0.414 \\
\hline & & & {$[1.36]$} & [1.04] \\
\hline \multirow[t]{2}{*}{ regulation*b2509 } & & & -53.55 & -42.64 \\
\hline & & & {$[-1.64]$} & {$[-1.32]$} \\
\hline Individual control variable & YES & YES & YES & YES \\
\hline Urban control variable & YES & YES & YES & YES \\
\hline $\mathrm{N}$ & 7842 & 7842 & 7841 & 7841 \\
\hline \multicolumn{5}{|c|}{ Panel B: environmental regulation indicators and environmental awareness indicators changed } \\
\hline \multirow[t]{2}{*}{ regulation } & $0.963 * * *$ & $0.916^{* * *}$ & & \\
\hline & [3.55] & [3.39] & & \\
\hline \multirow[t]{2}{*}{ b21a04 } & $0.420 *$ & 0.17 & & \\
\hline & [2.18] & [0.89] & & \\
\hline \multirow[t]{2}{*}{ regulation *b21a04 } & $-0.687^{*}$ & -0.372 & & \\
\hline & {$[-2.51]$} & {$[-1.36]$} & & \\
\hline \multirow[t]{2}{*}{ regulation } & & & $1.207^{* * *}$ & $1.039 * * *$ \\
\hline & & & [4.74] & [4.11] \\
\hline \multirow[t]{2}{*}{ b21a10 } & & & $0.652 * * *$ & 0.3 \\
\hline & & & [3.55] & [1.64] \\
\hline \multirow[t]{2}{*}{ regulation * b21a10 } & & & $-1.059 * * *$ & $-0.558 *$ \\
\hline & & & {$[-4.00]$} & {$[-2.12]$} \\
\hline Individual control variable & YES & YES & YES & YES \\
\hline Urban control variable & YES & YES & YES & YES \\
\hline $\mathrm{N}$ & 7841 & 7841 & 7838 & 7838 \\
\hline
\end{tabular}

\subsection{Further Research}

Through the above analysis, we know that environmental regulation can improve environmental governance satisfaction, while environmental awareness will weaken environmental governance satisfaction. What are the possible influence paths of these two explanatory variables on environmental governance satisfaction? This section attempts to answer this question.

Environmental regulations are intended to deal with pollution. If the environmental regulation policy is implemented, the public may think that environmental pollution has been improved. It will also improve their satisfaction with the government's environmental governance. To verify this path, we analyze it with Equation (8). The environmental quality indicators are b21b01 "what is the severity of air pollution in your area?" and b21b02 "what is the severity of water pollution in your area?" (the values are 1 7. It indicates from "no problem" to "very serious"). Environmental regulation selects a positive indicator that is synthesized by the removal rates of various pollutants. Other control variables are the same as before. The specific results are shown in columns 1 2 of Table 8. Environmental 
regulation is significantly negatively related to pollution problems in the region. It indicates that with the implementation of environmental regulation, the public believes the pollution problem in their area decreased. Then their satisfaction with environmental governance improved.

$$
\text { Environment }_{i j}=\mathrm{F}\left(\alpha \text { Regulation }_{i j}+\gamma p_{i j}+\varphi q_{j}+\varepsilon_{i j}\right)
$$

Environmental awareness is the public's cognition of environmental problems, that is, whether the public is aware of various types of environmental pollution problems. If the public has a certain understanding of environmental pollution, it may promote the public to pay attention to environmental problems and environmental protection information. It also improves their requirements for environmental governance. Furthermore, it is more rigorous to identify the satisfaction with government environmental governance. If the public has a certain awareness of environmental pollution, it will enhance the possibility of actively discussing environmental protection with relatives and friends around. Furthermore, it may increase the public's demand for higher environmental governance, to have a higher evaluation standard of environmental governance satisfaction. To verify these two paths, we will analyze them in combination with Equation (9). The explanatory variables were b2202 "discuss environmental issues with your relatives and friends" and b2206 "actively pay attention to environmental issues and environmental information reported in radio, television, and newspaper" in CGSS (2013) (the values are: never $=1$, occasionally $=2$, often $=3$ ). The explanatory variables were still b21a01 and b21a02. Other control variables are the same as before. The specific results are shown in $3 \sim 6$ columns in Table 8 . Environmental awareness has a significant positive effect on the public's discussion of environmental protection issues with their relatives and friends. Environmental awareness also has a significant positive effect on active attention to environmental issues and environmental information reported in radio, television, and newspapers. It shows that the public's awareness of environmental pollution can improve the requirements for environmental quality. Then the evaluation of environmental governance satisfaction will be affected.

$$
\text { Concern }_{i j}=\mathrm{F}\left(\beta \text { Awareness }_{i j}+\gamma p_{i j}+\varphi q_{j}+\varepsilon_{i j}\right)
$$

\begin{tabular}{|c|c|c|c|c|c|c|}
\hline & b21b01 & b21b02 & b2202 & b2202 & b2206 & b2206 \\
\hline regulation & $\begin{array}{l}-0.426 \text { * } \\
{[-2.53]}\end{array}$ & & & & & \\
\hline regulation & & $\begin{array}{l}-0.847^{* * *} \\
{[-5.07]}\end{array}$ & & & & \\
\hline b21a01 & & & $\begin{array}{l}0.352 * * * \\
{[5.49]}\end{array}$ & & & \\
\hline b21a02 & & & & $\begin{array}{l}0.4433^{* * *} \\
{[7.35]}\end{array}$ & & \\
\hline b21a01 & & & & & $\begin{array}{l}0.444^{* * *} \\
{[6.92]}\end{array}$ & \\
\hline b21a02 & & & & & & $\begin{array}{l}0.398^{* * *} \\
{[6.74]}\end{array}$ \\
\hline Individual control variable & YES & YES & YES & YES & YES & YES \\
\hline Urban control variable & YES & YES & YES & YES & YES & YES \\
\hline $\mathrm{N}$ & 7380 & 7339 & 7831 & 7831 & 7829 & 7829 \\
\hline
\end{tabular}

Table 8. Analysis of influence mechanism.

\section{Conclusions}

This paper studied the impact of environmental regulation and environmental awareness on environmental governance satisfaction with the data of the Chinese General Social Survey (CGSS) in 2013. The result shows that environmental regulation has a significant positive impact on environmental governance satisfaction, while environmental awareness has a significant negative impact on environmental governance satisfaction. We also found 
that when public environmental awareness is taken into account, the positive relationship between environmental regulation and environmental governance satisfaction is affected. Environmental pollution may impact people's perceptual domain and thus affect their well-being $[25,26]$. Environmental regulation may improve the public's satisfaction with environmental governance by improving their subjective perception of environmental quality. Environmental awareness may affect the evaluation criteria of public satisfaction with environmental governance. It may also affect public satisfaction with environmental governance.

In general, the public thinks environmental regulation can control environmental pollution. That is, environmental regulation and environmental governance satisfaction are positively related. However, with the enhancement of environmental awareness, the public's demand for environmental quality has increased. The positive relationship between environmental regulation and environmental governance satisfaction is negatively affected. Therefore, in evaluating the policy effect of government environmental regulation, public participation is conducive to expanding the evaluation perspective of policy effect and enhancing the credibility of environmental regulation effect. Meanwhile, the public's environmental governance evaluation is conducive to urging the government to control environmental pollution and promoting the realization of "ecological benefits for the people".

Author Contributions: The authors contribute equally in the project. L.-Y.H. conceived the whole project and acquired funding supports for it. M.-M.G. calculated the results under L.-Y.H.'s supervision. L.-Y.H. and M.-M.G. analyzed the data, discussed the results, and co-wrote the manuscript. All authors have read and agreed to the published version of the manuscript.

Funding: This project is supported by the State Major and Key Project of the National Social Science Foundation of China (Grant Nos. 20\&ZD109, 19AZD003), the National Natural Science Foundation of China (Grant Nos. 71874070, 71573258), and by Guangdong Province Universities and Colleges Pearl River Scholar Funded Scheme (2019).

Institutional Review Board Statement: Not applicable.

Informed Consent Statement: Not applicable.

Data Availability Statement: Data was obtained from China Statistical Yearbook, China Environmental Statistical Yearbook, China environment database in EPS, and Chinese General Social Survey.

Conflicts of Interest: The authors declare no conflict of interest.

\section{References}

1. China Statistical Yearbook in 2020. Available online: Http://www.stats.gov.cn/tjsj/ndsj/2020/indexch.htm (accessed on 3 October 2020).

2. China Ecological Environment Bulletin in 2017. Available online: Http://www.mee.gov.cn/hjzl/sthjzk/zghjzkgb/ (accessed on 3 October 2020).

3. Baike. Available online: https://baike.so.com/doc/6944416-7166779.html (accessed on 3 October 2020).

4. Tong, Z.F. Reflections on environmental mass incidents in China. In The China Environment Yearbook; Ministry of Ecology and Environment: Beijing, China, 2009, pp. 235-248.

5. Zhang, B. Chen, X. Guo, H. Does central supervision enhance local environmental enforcement? Quasi-experimental evidence from China. J. Public Econ. 2018, 164, 70-90. [CrossRef]

6. Guo, S.; Wang, W.; Zhang, M. Exploring the impact of environmental regulations on happiness: New evidence from China. Environ. Sci. Pollut. Res. 2020, 27, 19484-19501. [CrossRef]

7. Zhang, B.; Bi, J.; Yuan, Z.; Ge, J.; Liu, B.; Bu, M. Why do firms engage in environmental management? An empirical study in China. J. Clean. Prod.2008, 16, 1036-1045. [CrossRef]

8. Zhou, Q.; Zhang, X.; Shao, Q.; Wang, X. The non-linear effect of environmental regulation on haze pollution: Empirical evidence for 277 Chinese cities during 2002-2010. J. Environ. Manag. 2019, 248, 109274. [CrossRef]

9. Wang, K.; Yin, H.; Chen, Y. The effect of environmental regulation on air quality: A study of new ambient air quality standards in China. J. Clean. Prod. 2019, 215, 268-279. [CrossRef]

10. Pei, Y.; Zhu, Y.; Liu, S.; Wang, X.; Cao, J. Environmental regulation and carbon emission: The mediation effect of technical efficiency. J. Clean. Prod. 2019, 236, 117599. [CrossRef] 
11. Zhou, A.; Li, J. Impact of income inequality and environmental regulation on environmental quality: Evidence from China. J. Clean. Prod. 2020, 274, 123008. [CrossRef]

12. Pang, R.; Zheng, D.; Shi, M.J.; Zhang, X.L. Pollute first, control later? Exploring the economic threshold of effective environmental regulation in China's context. J. Environ. Manag. 2019, 248, 109275. [CrossRef] [PubMed]

13. Wang, Y.; Sun, X.; Guo, X. Environmental regulation and green productivity growth: Empirical evidence on the Porter Hypothesis from OECD industrial sectors. Energy Policy 2019, 132, 611-619. [CrossRef]

14. Shen, N.; Liao, H.; Deng, R.; Wang, Q. Different types of environmental regulations and the heterogeneous influence on the environmental total factor productivity: Empirical analysis of China's industry. J. Clean. Prod. 2019, 211, 171-184. [CrossRef]

15. Zhu, X.; Zeng, A.; Zhong, M.; Huang, J.; Qu, H. Multiple impacts of environmental regulation on the steel industry in China: A recursive dynamic steel industry chain CGE analysis. J. Clean. Prod. 2019, 210, 490-504. [CrossRef]

16. Wang, C.; Zhang, Y.J. Does environmental regulation policy help improve green production performance? Evidence from China's industry. Corp. Soc. Responsib. Environ. Manag. 2020, 27, 937-951. [CrossRef]

17. Chen, X.; Huang, B.; Lin, C.T. Environmental awareness and environmental Kuznets curve. Econ. Model. 2019, 77, 2-11. [CrossRef]

18. Teng, M.; He, X. Air quality levels, environmental awareness and investor trading behavior: Evidence from stock market in China. J. Clean. Prod. 2019, 244, 118663. [CrossRef]

19. Rustam, A.; Wang, Y.; Zameer, H. Environmental awareness, firm sustainability exposure and green consumption behaviors. J. Clean. Prod. 2020, 268, 122016. [CrossRef]

20. Cao, H.; Chen, Z. The Driving Effect of Internal and External Environment on Green Innovation Strategy: The Moderating Role of Top Management's Environmental Awareness. Nankai Bus. Rev. 2017, 10, 342-361. [CrossRef]

21. Huang, Q.; Chen, X.; Zhou, M.; Zhang, X.; Duan, L. How Does CEO's Environmental Awareness Affect Technological Innovation? Int. J. Environ. Res. Public Health 2019, 16, 261. [CrossRef] [PubMed]

22. He, X.; Liu, Y. The public environmental awareness and the air pollution effect in Chinese stock market. J. Clean. Prod. 2018, 185, 446-454. [CrossRef]

23. Loewenstein, G.F. Emotions in economic theory and economic behavior. Am. Econ. Rev. 2000, 90, 426-432. [CrossRef]

24. Loewenstein, G.F.; Weber, E.U.; Hsee, C.K.; Welch, N. Risk as feelings. Psychol. Bull. 2001, 127, 267. [CrossRef]

25. Li, Y.; Guan, D.B.; Shu, T.; Wang, X.J.; He, K.B. A review of air pollution impact on subjective well-being: Survey versus visual psychophysics. J. Clean. Prod. 2018, 184, 959-968. [CrossRef]

26. Liao, P.S.; Shaw, D.; Lin, Y.M. Environmental quality and life satisfaction: Subjective vs. objective measures of air quality. Soc. Indic. Res. 2015, 124, 599-616. [CrossRef]

27. Chandrashekaran, M.; Rotte, K.; Grewal, T.R. Satisfaction Strength and Customer Loyalty. J. Mark. Res. 2007, 44, 153-163. [CrossRef]

28. Ferreira, S.; Akay, A.; Brereton, F.; Cunado, J.; Martinsson, P.; Moro, M.; Ningal, T.F. Life satisfaction and air quality in Europe. Ecol. Econ. 2013, 88, 1-10. [CrossRef]

29. Shi, X.M. Factors Influencing the Environmental Satisfaction of Local Residents in the Coal Mining Area, China. Soc. Indic. Res. 2015, 120, 67-77. [CrossRef]

30. Barrington-Leigh, C.; Behzadnejad, F. Evaluating the short-term cost of low-level local air pollution: A life satisfaction approach. Environ. Econ. Policy Stud. 2016, 19, 269-298. [CrossRef]

31. Orru, K.; Orru, H.; Maasikmets, M.; Hendrikson, R.; Ainsaar, M. Well-being and environmental quality: Does pollution affect life satisfaction?. Qual. Life Res. 2016, 25, 699-705. [CrossRef] [PubMed]

32. Majeed, M.T.; Mumtaz, S. Happiness and environmental degradation: A global analysis. Pak. J. Commer. Soc. Sci. 2017, 11, 753-772.

33. Yuan, L.; Shin, K.; Managi, S. Subjective Well-being and Environmental Quality: The Impact of Air Pollution and Green Coverage in China. Ecol. Econ. 2018, 153, 124-138. [CrossRef]

34. Chen, L.; Zhang, J.; You, Y. Air pollution, environmental perceptions, and citizen satisfaction: A mediation analysis. Environ. Res. 2020, 184, 109287. [CrossRef]

35. Han, A.; Khan, T.G.; Wang, S. Gray Skies and Blue Moms: The Effect of Air Pollution on Parental Life Satisfaction. In KDI School of Pub Policy \& Management Paper; Paper No.\#20-14; KDI School: Seoul, Korea, 2020.

36. Knight, S.J.; Howley, P. Can clean air make you happy? Examining the effect of nitrogen dioxide $\left(\mathrm{NO}_{2}\right)$ on life satisfaction. In Health, Econometrics and Data Group (HEDG) Working Papers; Department of Economics, University of York: York, UK, 2017.

37. Levinson, A. Valuing public goods using happiness data: The case of air quality. J. Public Econ. 2012, 96, 869-880. [CrossRef]

38. Du, G.; Shin, K.J.; Managi, S. Variability in impact of air pollution on subjective well-being. Atmos. Environ. 2018, 183, 175-208. [CrossRef]

39. Silva, J.; Keulenaer, F.; Johnstone, N. Environmental Quality and Life Satisfaction: Evidence Based on Micro-Data. In OECD Environment Working Papers; No.44; OECD Publishing: Paris, France, 2012.

40. Ferreira, S.; Moro, R. On the Use of Subjective Well-Being Data for Environmental Valuation. Environ. Resour. Econ. 2010, 46, 249-273. [CrossRef]

41. Luechinger, S. Life satisfaction and transboundary air pollution. Econ. Lett. 2010, 107, 4-6. [CrossRef]

42. Menz, T. Do people habituate to air pollution? Evidence from international life satisfaction data. Ecol. Econ. 2011, 71, 211-219. [CrossRef] 
43. Li, Z.; Folmer, H.; Xue, J. To what extent does air pollution affect happiness? The case of the Jinchuan mining area, China. Ecol. Econ. 2014, 99, 88-99. [CrossRef]

44. Wang, B. Z.; Cheng, Z. Environmental perceptions, happiness and pro-environmental actions in China. Soc. Indic. Res. 2017, 132, 357-375. [CrossRef]

45. Song, Y.; Li, M.; Zhang, M.; Sun, X. Study on the impact of air pollution control on urban residents' happiness from microscopic perspective. J. Clean. Prod. 2019, 229, 1307-1318. [CrossRef]

46. Jannah, M.; Halim, L.; Meerah, S.; Fairuz, M. Subahan Mohd, Fairuz, Muhammad. Impact of Environmental Education Kit on Students' Environmental Literacy. Asian Soc. Sci. 2013, 9, 1-12. [CrossRef]

47. Ham, M.; Mrčela, D.; Horvat, M. Insights for measuring environmental awareness. Ekon. Vjesn. 2016 29, $159-176$.

48. Liu, X.; Vedlitz, A.; Shi, L. Examining the determinants of public environmental concern: Evidence from national public surveys. Environ. Ence Policy 2014, 39, 77-94. [CrossRef]

49. Umuhire, M.L.; Fang, Q. Method and application of ocean environmental awareness measurement: Lessons learnt from university students of China. Mar. Pollut. Bull. 2016, 102, 289-294. [CrossRef] [PubMed]

50. Maas, A.; Goemans, C.; Manning, D.; Kroll, S.; Arabi, M.; Rodriguez-McGoffin, M. Evaluating the effect of conservation motivations on residential water demand. J. Environ. Manag. 2017, 196, 394-401. [CrossRef]

51. Lucio, M.; Giulia, R.; Lorenzo, C. Investigating attitudes towards water savings, price increases, and willingness to pay among italian university students. Water Resour. Manag. 2018, 32, 4123-4138. [CrossRef]

52. Liu, P.; Teng, M.; Han, C. How does environmental knowledge translate into pro-environmental behaviors?: The mediating role of environmental attitudes and behavioral intentions. Sci. Total Environ. 2020, 728, 138126. [CrossRef]

53. Faccioli, M.; Czajkowski, M.; Glenk, K.; Martin-Ortega, J. Environmental attitudes and place identity as determinants of preferences for ecosystem services. Ecol. Econ. 2020, 174, 106600. [CrossRef]

54. Escario, J.J.; Rodriguez-Sanchez, C.; Casaló, L.V. The influence of environmental attitudes and perceived effectiveness on recycling, reducing, and reusing packaging materials in Spain. Waste Manag. 2020, 113, 251-260. [CrossRef]

55. Du, Y.; Wang, X.Y.; Brombal, D.; Moriggi, A.; Sharpley, A.; Pang, S.J. Changes in Environmental Awareness and Its Connection to Local Environmental Management in Water Conservation Zones: The Case of Beijing, China. Sustainability 2018, $10,2087$. [CrossRef]

56. Rajapaksa, D.; Gifford, R.; Torgler, B.; Garcia-Vali $\widetilde{n}$ as, M.; Athukorala, W.; Managi, S.; Wilson, C. Do monetary and non-monetary incentives influence environmental attitudes and behavior? Evidence from an experimental analysis. Resour. Conserv. Recycl. 2019, 149, 168-176. [CrossRef]

57. Sirgy, M.J.; Widgery, R.N.; Lee, D.J.; Yu, G.B. Developing a measure of community well-being based on perceptions of impact in various life domains. Soc. Indic. Res. 2010, 96, 295-311. [CrossRef]

58. Ferrer-i-Carbonell, A.; Gowdy, J.M. Environmental degradation and happiness. Ecol. Econ. 2007, 60, 509-516. [CrossRef]

59. Cole, M.A.; Elliott, R.J.R. Do Environmental Regulations Influence Trade Patterns? Testing Old and New Trade Theories. World Econ. 2003, 26, 1163-1186. [CrossRef]

60. Lanoie, P.; Patry, M.; Lajeunesse, R. Environmental regulation and productivity: Testing the porter hypothesis. J. Product. Anal. 2008, 30, 121-128. [CrossRef]

61. Mani, M.; Wheeler, D. In search of pollution havens? Dirty industry in the world economy, 1960 to 1995. J. Environ. Dev. 1998, 7, 215-247. [CrossRef]

62. Levinson, A. Environmental regulations and manufacturers' location choices: Evidence from the Census of Manufactures. J. Public Econ. 1996, 62, 5-29. [CrossRef]

63. Domazlicky, B.R.; Weber, W.L. Does Environmental Protection Lead to Slower Productivity Growth in the Chemical Industry?. Environ. Resour. Econ. 2004, 28, 301-324. [CrossRef]

64. Fisman, R.; Svensson, J. Are corruption and taxation really harmful to growth? Firm level evidence. J. Dev. Econ. 2007, 83, 63-75. [CrossRef] 